\title{
SPECTROSCOPIC AND ANCIENT GEOMAGNETIC FIELD INTENSITY STUDIES ON ARCHAEOLOGICAL POTTERY SAMPLES, INDIA
}

\author{
C. Manoharan ${ }^{\mathrm{a}}$, K. Veeramuthu ${ }^{\mathrm{a}}$, R. Venkatachalapathy ${ }^{\mathrm{b}}$, T. Radhakrishna $^{\mathrm{c}}$, and \\ R. Ilango ${ }^{\mathrm{d}}$ \\ a Department of Physics, Annamalai University, Annamalainagar - 608 002, India \\ E-mail: cmanoharan1@ rediffmail.com \\ ${ }^{\mathrm{b}}$ C. A. S. in Marine Biology, Annamalai University, Parangipettai- 608 502, India \\ ${ }^{\mathrm{c}}$ Centre for Earth Science Studies, Akkulam, Trivandrum - 695 031, India \\ ${ }^{\mathrm{d}}$ Department of Physics, RKM Vivekananda College, Mylapore, Chennai-600 004, Tamil Nadu, India
}

Received 11 April 2008; revised 5 June 2008; accepted 9 June 2008

\begin{abstract}
Spectroscopic and paleointensity studies have been performed on archaeological pottery samples from Mayiladumparai, Tamilnadu, India. The clay mineral type and its level of structural deformation due to firing were studied from their Fourier Transform Infrared (FTIR) Spectra. The maximum firing temperature attained during baking, firing conditions (open / reduced atmospheric) and iron mineral phase changes were well established. Intensive rock magnetic properties on these samples were carried out in order to select the samples for paleointensity measurements. The results showed that all the samples were magnetically enhanced having superparamagnetic grains with Curie temperature of magnetite $\left(580^{\circ} \mathrm{C}\right)$ and yielded mean paleointensity value of $48.71 \pm 0.16 \mu \mathrm{T}$.
\end{abstract}

Keywords: archaeological artifacts, FTIR and paleointensity

PACS: 33.20.Ea, 91.25.Dx, 75.30.Cr

\section{Introduction}

Pottery occupies a unique position by its distinguishing and characteristic, features as well as by its distribution in different areas and periods. Pottery is helpful for identification of a civilisation, inasmuch as it is an essential element to characterize it [1]. The value of pottery for studying the culture of a particular groups of people in a particular region and period is considerable. A careful study of pottery helps one to identify the different cultural groups and their influence on one another. Pottery, being the common man's property and a popular industry among the society, throws enough light on everyday life. The richness of pottery, judged by its fabric, polishing, glazing, slips, paintings, and decorative designs, reflects the economic conditions and the aesthetic tastes of the people who used it. The beginning and end of a particular culture or civilisation may also be determined with the help of pottery.

Clays, in fact, very rarely used as they are. The aim of the potter is to obtain a material characterised by a plastic state. This state occurs when the mixture can be moulded and formed without breaking the paste material. Once the forces of shaping are relaxed, the material maintains its structure and shape. The plastic state depends upon the proportions of clay, water, and nonplastic material (temper grains). Temper grains can be naturally present in the clay or added by potter during process of making a paste. If clays contain too much non-plastic temper, the potter will decant out of the coarse material concentrating the clay fraction and, in the end, he will need to add some temper again. Furthermore, a more complicated but quite common practice is to use two or more clay sources (characterised by different plasticity) as a base for a paste.

Clay, the chief ingredient used in pottery, is a finegrained material that develops some ductile behaviour when mixed with water. The main components of clay are $\mathrm{Si}, \mathrm{Al}$, and water, which also contains small amounts of feldspars, biotite, carbonates, Fe-Ti oxides, as well as soluble salts and organic matter. The most common Fe minerals in clays especially important in archaeomagnetic studies are hematite, goethite, limonite, magnetite, and siderite [2]. The making of pottery in- 
volves different steps [3] - collection and preparation of the clay, modelling of the artifacts, surface finishing, decoration, drying, and hardening by heat. Clay firing is one of the earliest technological operations of mankind. Clay firing, if properly conducted with respect to material and process, produces exceedingly durable artifacts. Scientific studies are used to explore the technological development of the prehistoric man. The clay intended for making vessels is devoid of impurities and possesses fine plasticity, the vessels made out of it will be of a better quality.

The clay minerals as well as associated minerals including iron oxides undergo characteristic chemical and physical changes during firing which can be followed by different techniques like X-ray diffraction, scanning electron microscopy, differential thermal analysis, optical microscopy, Mössbauer studies, FTIR, etc. Of the various well-known methods of analysis, infrared absorption spectroscopy is a rapid, economical, and non-destructive physical method universally applicable for structural analysis of clay minerals. Infrared spectroscopy is a sensitive technique to monitor dyhydroxylation and dehydration of clay minerals [4]. On firing the clay materials the structural deformation of the clay minerals and associated minerals depend upon firing temperature and atmosphere, which can be followed by FTIR [5-8]. Knowledge of the firing temperature can be of value in other scientific investigations of ancient ceramics and kilns, such as thermo-luminescence and magnetic dating.

Archaeomagnetic study is primarily based on the determination of the paleointensity using baked clays. These clays usually carry a stable remanent magnetisation which has "fossilized" the direction and intensity of geomagnetic field at the time and in the place of its last firing $[9,10]$. The necessary condition for determining the suitability of the materials for archaeomagnetic investigation is that they must be heated to high temperature, i.e. above Curie temperature of the respective minerals, which fossilize the earth's magnetic field and its direction. The type of magnetic minerals (remanence carriers), their concentration and domain states are important factors in determining the reliability of the results possessed by the artifacts [9-11]. The artifacts are subjected to rock magnetic studies like magnetic susceptibility (frequency and temperature) and isothermal remanent magnetisation (IRM) acquisition in order to characterise the main magnetic phases and to select the most suitable samples for paleointensity measurements.

For the present study the archaeological pottery samples (broken body pieces of red ware/black and red ware) belonging to Iron Age were collected from Mayiladumparai (MPI) (lat. $12^{\circ} 32^{\prime} \mathrm{N}$, long. $77^{\circ} 32^{\prime} \mathrm{E}$ ) Krishnagiri District, Tamilnadu, India. Samples were subjected to FTIR and archaeomagnetic studies in order to reveal the firing temperature, firing conditions, mineral magnetic and paleointensity values.

\section{Experimental methods}

The FTIR absorption spectra were recorded in the frequency region of $4000-400 \mathrm{~cm}^{-1}$, using model Paragon 500, Perkin-Elmer spectrophotometer with 16 scan mode by using standard $\mathrm{KBr}$ pellet technique. The accuracy of the measurement was $\pm 4 \mathrm{~cm}^{-1}$ in 4000 to $2000 \mathrm{~cm}^{-1}$ region and $\pm 2 \mathrm{~cm}^{-1}$ in 2000 to $400 \mathrm{~cm}^{-1}$ region. Magnetic susceptibility measurements were carried out using a dual frequency Bartington MS2B susceptibility meter at two frequencies ( $\chi_{\mathrm{LF}}$ at $0.47 \mathrm{kHz}$ and $\chi_{\mathrm{HF}}$ at $4.7 \mathrm{kHz}$ ).

The parameters, mass-specific frequency-dependent susceptibility $\chi_{\mathrm{FD}}$ defined as $\chi_{\mathrm{FD}}=\chi_{\mathrm{LF}}-\chi_{\mathrm{HF}}$ and percentage frequency-dependent susceptibility $\chi_{\mathrm{FD}} \%$ defined as $\chi_{\mathrm{FD}} \%=\left(\chi_{\mathrm{LF}}-\chi_{\mathrm{HF}}\right) / \chi_{\mathrm{LF}} \cdot 100$, are used to detect ultrafine $(<0.03 \mu \mathrm{m})$ ferrimagnetic minerals lying in the superparamagnetic grain size $[12,13]$. Temperature dependence of magnetic susceptibility $\chi-T$ (in air atmosphere) was measured using Bartington MS2WFB with high temperature furnace by heating samples up to $700{ }^{\circ} \mathrm{C}$ and cooling down to $100^{\circ} \mathrm{C}$ in steps of $2{ }^{\circ} \mathrm{C}$. Saturation isothermal remanent magnetization (SIRM) studies were conducted using pulse magnetizer (IM-1030 Impulse Magnetizer, ASC Scientific, USA). Remanence intensity was measured with an Agico Molspin spinner magnetometer with a measuring accuracy of $\pm 2.4 \cdot 10^{-6} \mathrm{~A} / \mathrm{m}$. The paleointensity values are derived by subjecting the suitable samples to modified Thellier and Thellier method using Magnetic Measurements Thermal Demagnetiser (MMTD, UK).

\section{Results and discussion}

\subsection{FTIR studies}

Infrared absorption bands characteristic of clay minerals are observed in all the samples with deformed state. To study the level of deformation, the spectra of heated samples in laboratory furnace at 300, 500, and $800^{\circ} \mathrm{C}$ is compared with the spectra of the received state. FTIR spectra of selected pottery samples MPI-1 

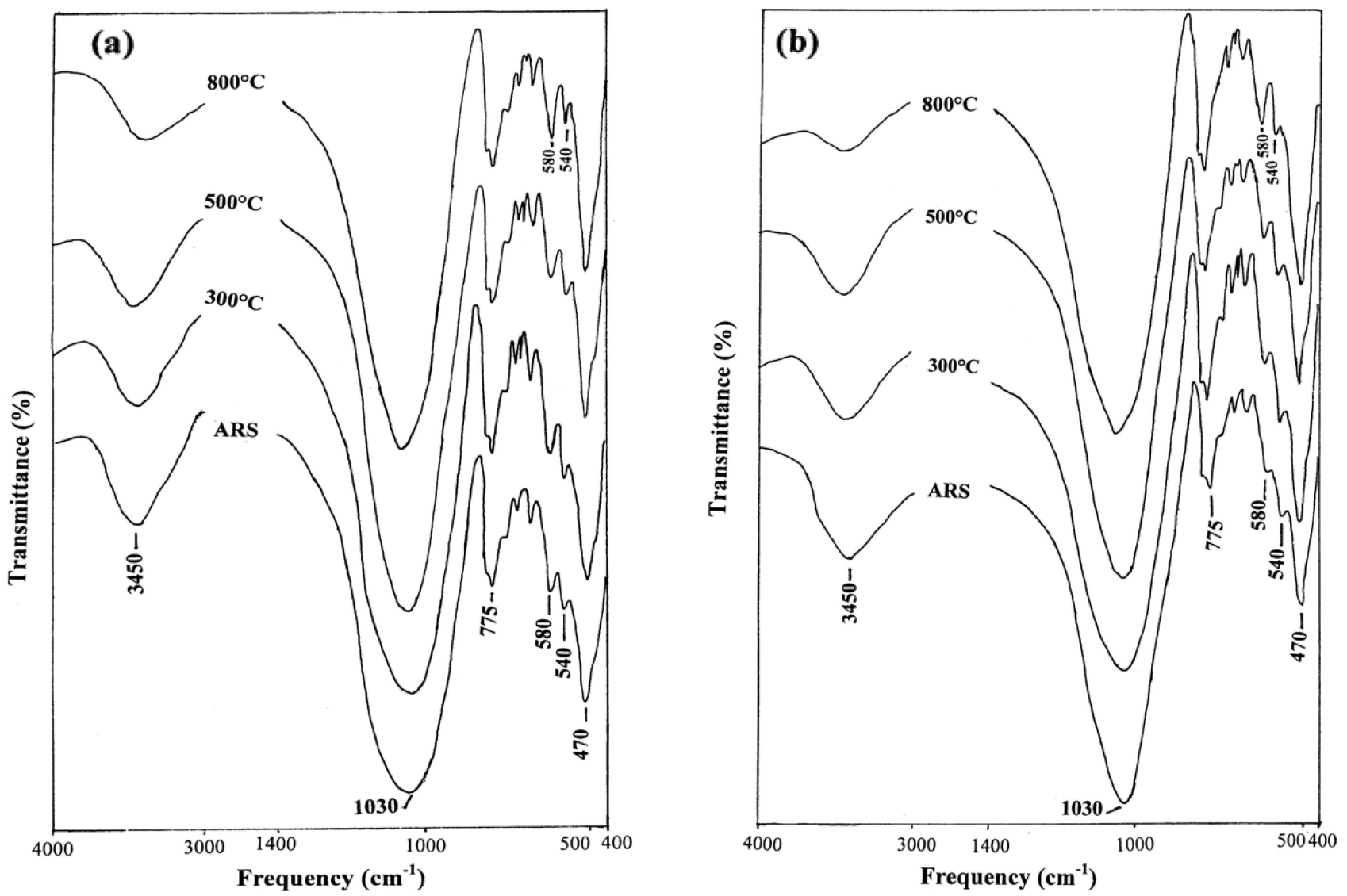

Fig. 1. FTIR absorption spectra of Mayiladumparai pottery samples: (a) MPI-1, (b) MPI-2.

and MPI-2 in as received state and refired at 300,500, and $800^{\circ} \mathrm{C}$ are shown in Fig. 1 .

When clay is fired between $300-500^{\circ} \mathrm{C}$, dehydroxylation of octahedral layers of most clay minerals takes place [14]. The onset of dehydroxylation is reflected by marked attenuation of the bands due to $\mathrm{Al} \mathrm{Al}-\mathrm{OH}$ in-plane vibration at $920 \mathrm{~cm}^{-1}$ and translational vibrations involving $\mathrm{OH}$ at $522 \mathrm{~cm}^{-1}$ [7]. At $600{ }^{\circ} \mathrm{C}$, the silicate structure collapses and a broad symmetry band is observed at $1030 \mathrm{~cm}^{-1}$ for red clay and $1080 \mathrm{~cm}^{-1}$ for white clay type [15]. Venkatachalapathy et al. [6] have established the dehydroxylation and destruction of layer silicates of clay minerals by firing model clay (Nathikudi) in steps from 50 up to $800{ }^{\circ} \mathrm{C}$. The intensity of hydroxyl bands at 3700 region, 1100 , and $920 \mathrm{~cm}^{-1}$ decreases and disappears in between $400-600^{\circ} \mathrm{C}$, due to the onset of dehydroxylation. The appearance of the 540 and $580 \mathrm{~cm}^{-1}$ bands attributed to iron oxides at $600^{\circ} \mathrm{C}$, with marked attenuation of the $530 \mathrm{~cm}^{-1}$ band in between $400-600^{\circ} \mathrm{C}$ is well established. Wagner et al. [14] reported that the formation of crystalised hematite in clays have been observed in between 700 and $900{ }^{\circ} \mathrm{C}$, from the Mössbauer spectral analysis.

The presence of iron oxides in the region of 700
$400 \mathrm{~cm}^{-1}$ formed during the firing process of clay is due to the replacement of aluminium by iron. Some iron oxides that do not normally occur in natural clays may form during firing of pottery. Magnetite may form during firing under reducing condition [8]. On refiring the pottery in laboratory (oxidising) condition, reoxidation of iron oxides takes place in between 400 and $600{ }^{\circ} \mathrm{C}$, which is reflected by the changes in intensity of the bands at 540 and $580 \mathrm{~cm}^{-1}$. The formation of crystalline hematite is observed above $800^{\circ} \mathrm{C}$. Ishii and Nakahira [14] point out that the peak appearing at $572 \mathrm{~cm}^{-1}$ is due to $\mathrm{Fe}-\mathrm{O}$ vibration of iron oxide, but exact nature of oxide could not be determined from the IR spectrum.

The presence of sharp band around 790 along with $695 \mathrm{~cm}^{-1}$ in all samples is due to the presence of quartz (Si-O) [4]. Quartz and feldspar are often present in pottery clays either because they are present already in the raw clay, or because they are added as temper. The bands occurring at 462 and $514 \mathrm{~cm}^{-1}$ are assigned to mixed $\mathrm{Si}-\mathrm{O}-\mathrm{Si}$ and $\mathrm{O}-\mathrm{Si}-\mathrm{O}$ bending mode [17]. The band at $470 \mathrm{~cm}^{-1}$ due to $\mathrm{Si}-\mathrm{O}$ band is free from any temperature effects.

The absence of hydroxyl bands and the presence of 
broad symmetry band centred around $1030 \mathrm{~cm}^{-1}$ in the as received state spectra indicate that the samples MPI-1 (red ware) and MPI-2 (black and red ware) have been fired above $600^{\circ} \mathrm{C}$ and made up of disordered clay $[6,7]$. The well resolved and distinct peaks at 540 and $580 \mathrm{~cm}^{-1}$ in the spectra of as received state in both samples reveal the presence of iron oxides. It also confirms the firing temperature as above $600{ }^{\circ} \mathrm{C}[6]$. The prominent peak at 540 and $580 \mathrm{~cm}^{-1}$ in sample MPI-1 reveals that the sample is fired under reduced atmosphere. At the same time, air has been allowed at a higher temperature during cooling which has enabled the oxidation of iron components formed during reduced atmosphere, the reason for the red colour of the pottery. Allowing air during cooling is a common practice for coloration of the baked clays. In the case of as received state spectra of sample MPI-2, the band at 540 and weak shoulder at $580 \mathrm{~cm}^{-1}$ indicate that the sample is fired under strong reduced atmosphere and air is admitted only at lower temperature, the reason for inner black and outer red colour surface of the sample.

On refiring the above samples, no appreciable changes are observed up to $500^{\circ} \mathrm{C}$ and an increase in intensity of the bands at 540 and $580 \mathrm{~cm}^{-1}$ at $800^{\circ} \mathrm{C}$, indicating further oxidation and crystallisation of iron components.

From the FTIR studies, it is concluded that the samples MPI- 1 and MPI-2 have been fired above $600^{\circ} \mathrm{C}$ under different atmosphere (reducing followed by oxidising at higher temperature) and the clay used is of a disordered type.

\subsection{Mineral magnetic studies}

\subsubsection{Frequency dependent susceptibility}

Magnetic susceptibility $\chi$ describes the magnetic response of a sample when exposed to a (generally weak) magnetic field, and is mainly a function of the concentration, sample size, and mineralogy of the ferrimagnetic (magnetite, maghemite, Fe-sulphides) minerals present. It is customary to present susceptibility as mass-normalized susceptibility $\chi[18,19]$.

In the present study, magnetic susceptibility $\chi_{\mathrm{LF}}$ of pottery samples are more evenly spread over a wide interval $\left(15-73 \cdot 10^{-7} \mathrm{~m}^{3} / \mathrm{kg}\right)$ pointing to higher magnetic enhancement. Higher magnetic susceptibility values are most probably due to high degree of firing. Magnetic susceptibility is a magnetic characteristic which depends mainly on the concentration of ferrimagnetic minerals $[18,20]$. High values of $\chi_{\mathrm{FD}}$ indicate the presence of very fine-grained metastable magnetic grains spanning the superparamagnetic-stable single domain (SP-SSD) boundary [21]. All the samples show $\chi_{\mathrm{FD}} \%>2$ but most of the samples fall in between 4-10\% suggesting the presence of significant amount of the superparamagnetic magnetite grains. Jordanova [9] has reported that burnt clay samples with $\chi_{\mathrm{FD}} \%$ values of 6-10\% contain significant content of fine superparamagnetic magnetite grains of sizes $0.012-0.023 \mu \mathrm{m}$ [22]. The investigator's results suggest that the pottery samples under investigation are magnetically enhanced materials in terms of concentration and degree of crystallinity of magnetite.

\subsubsection{Temperature dependent susceptibility}

Temperature dependent susceptibility measurements are widely used for the determination of main magnetic minerals (using their Curie temperatures $T_{\mathrm{C}}$ ), which are responsible for acquiring ancient geomagnetic field, and the nature of mineral phase transformation, if any. Samples with basic reversibility of heating and cooling curves suggest no distinct mineralogical alteration occurred during heating, which are durable for paleointensity studies. Curves with irreversible behaviour are not suitable for paleointensity measurements [23, 24]. Jordanova et al. [9] have reported that the enormous increase in susceptibility values during cooling is most probably due to breakdown of clay minerals and formation of new strong ferrimagnetic phase indicating that these materials are not burnt to higher temperatures. The temperature dependent susceptibility curves for two representative samples are given in Fig. 2.

In the present investigation, the reversibility of the heating and cooling curves of all the MPI samples reveal that there is no distinct mineralogical changes and that magnetite, the main magnetic mineral, with Curie temperature around $580{ }^{\circ} \mathrm{C}$ is found. Hence the samples are suitable for paleointensity measurements. The presence of magnetite is also revealed by the drop of the initial susceptibility observed in the cooling curve, which is due to the oxidation of magnetite during heating to higher temperatures of $700^{\circ} \mathrm{C}$.

\subsubsection{IRM acquisition curves}

IRM is the remanent magnetization acquired by a sample after exposure to, and removal from a steady (DC) magnetic field. IRM depends on the strength of the field applied, which is often denoted by a subscript, and is also a function of the magnetic mineralogy and grain size. The maximum remanence that can be produced in a sample is called Saturation Isothermal Remanent Magnetization. IRM is often used as an indicator 


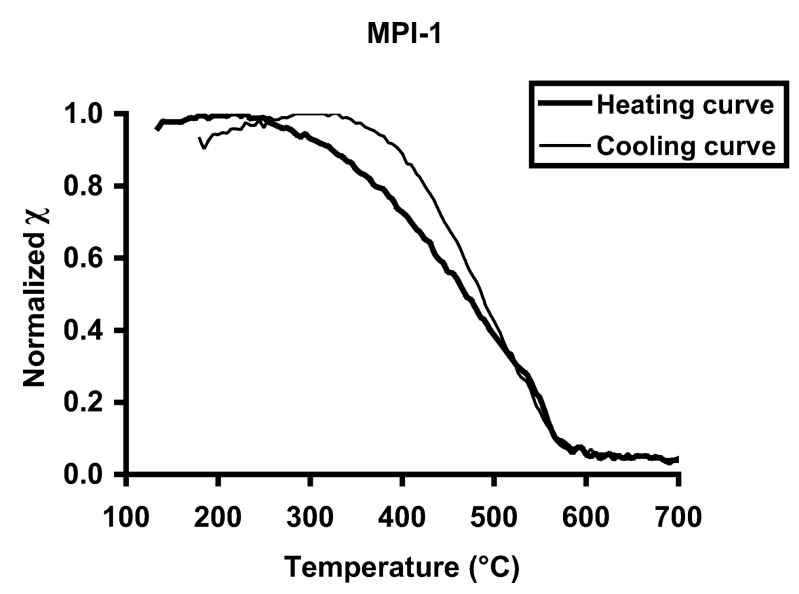

MPI-2

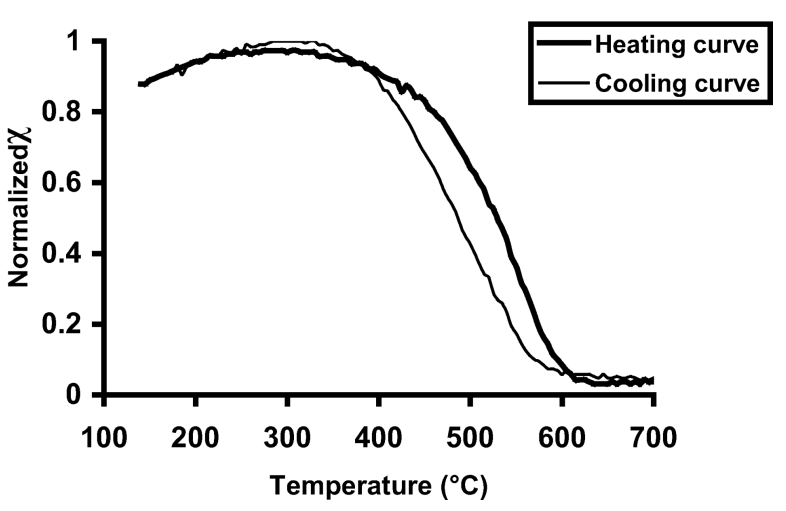

Fig. 2. Temperature dependent magnetic susceptibility.

for the presence of ferrimagnetic minerals, but also antiferromagnetic minerals, such as hematite and goethite, are also capable of acquiring an IRM. After a sample has acquired an IRM, it is often possible to (partially) demagnetize the sample by exposing it to a magnetic field in the reverse direction. Such a partial demagnetization can yield information about the ease of remanence acquisition, or the coercivity of a sample [19]. IRM acquisition curves give information about the coercivity distribution of a sample indicating the field at which the sample acquires its remanence. Tian et al. [23] and Zhu et al. [24] reported that the samples saturated by $300 \mathrm{mT}$ and showed a remanence coercivity of about 30-40 mT, indicating magnetite, probably the main magnetic carrier. The IRM acquisition curves for two representative samples are given in Fig. 3. In the present investigation all the samples show remanence coercivity of about $30-40 \mathrm{mT}$ suggesting that magnetisation is carried by low coercivity magnetic mineral such as magnetite/titanomagnetite with low Ti content. The S-ratio is $\mathrm{S}_{100}=\mathrm{IRM}_{-100} / \mathrm{SIRM}$, where IRM $_{-100}$ denotes an IRM acquired in a reverse field

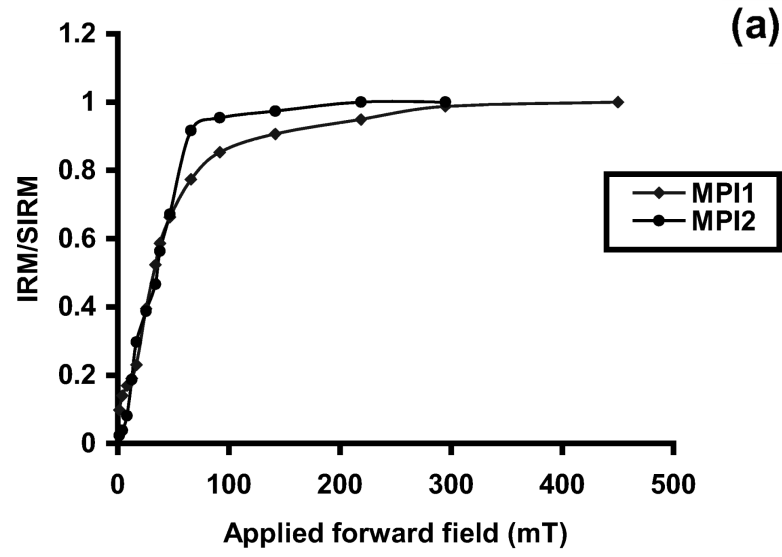

(b)

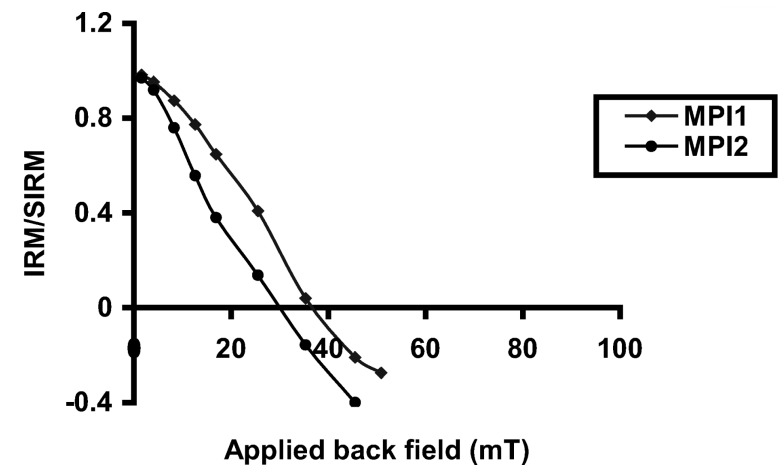

Fig. 3. (a) IRM acquisition and (b) back field DC demagnetisation curves.

of $100 \mathrm{mT}$ after SIRM acquisition. S-ratios can be used to gain information about the magnetic mineralogy [25]. S-ratios close to +1.0 are indicative of ferrimagnetic minerals while low S-ratios $(<0.6$ or even $<0)$ are caused by the presence of antiferromagnetic minerals. The studied samples show S-ratio values $>0.6$, which reflect the presence of ferrimagnetic minerals.

The magnetic parameter Königsberg ratio, Q-ratio = $\mathrm{NRM} / \chi_{\mathrm{LF}} \cdot 0.5$ Oe, gives the type of mineral and its domain state that produce a dominantly induced remanent magnetization [26]. The magnetization value of $0.5 \mathrm{Oe}$ corresponds to a magnetizing force of $39.79 \mathrm{~A} / \mathrm{m}$. The high Q-ratio values are characteristics of stable (thermoremanent) origin of NRM while low values $(Q<$ $1)$ are found for non-stable remanence $[21,27]$. The Q-ratios provide a relative importance of remanent and induced magnetization, being remanence-dominant for $Q>1$. Variations in remanent intensity and susceptibility depend on the volume content of magnetite. The Q-ratio > 1 indicates the presence of single domain/pseudo single domain (SD/PSD) magnetite grains in the samples. Cui and Verosub [28] have 


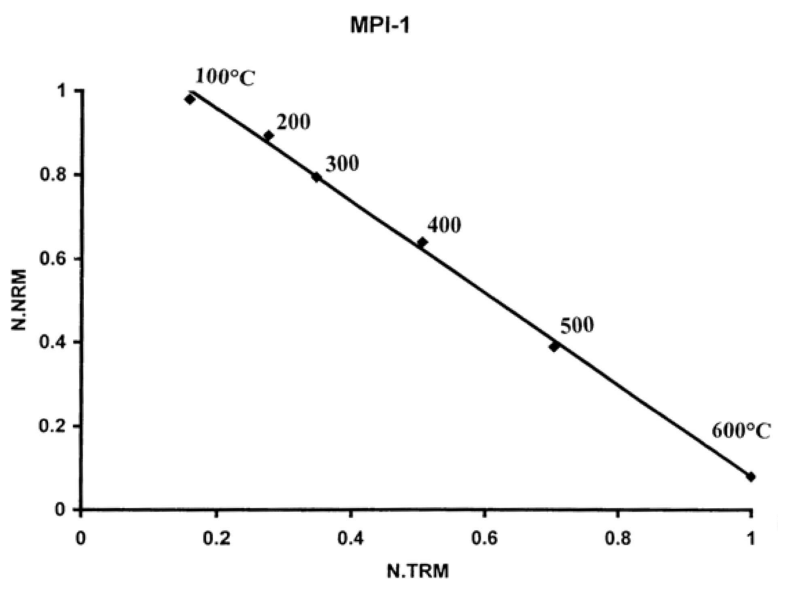

Fig. 4. Arai diagram of Mayiladumparai pottery MPI-1.

pointed out that in pottery samples a broad unblocking temperature distribution can arise from a grain size distribution that spans from superparamagnetic to single domain, and may be even to a pseudo-single domain. The broader the unblocking temperature distribution, the better the chances of retrieving the paleointensity before mineralogical changes occur.

\subsubsection{Paleointensity measurements}

Most paleointensity determinations using archaeological materials and lava flows are based on the modified Thellier and Thellier method [29] or modification of it $[30,31]$. The modified Thellier and Thellier method involves heating the sample in a zero field to a number of increasing temperature stages and measuring the intensity of magnetization remaining after each stage - its natural remanent magnetization (NRM). Once all the magnetization is removed, the process is repeated but with the sample exposed to a known reference magnetic field and the magnetisation measured is thermoremanent magnetisation (TRM). No chemical alterations are observed during Thellier double heating experiments. Thellier [32] suggests that the baked earth is the most suitable material for paleointensity determinations. A unique advantage of the Thellier method is that, as the heating temperature is progressively increased, magnetomineralogical alteration can be detected directly during the experiment using standard partial thermoremanent magnetisation (pTRM) checks [33]. The Arai plot has been drawn with the measured NRM and TRM magnetisation values. The Arai plot for one representative sample is shown in Fig. 4. The slope of the best fitting line to the linear part of the Arai diagram multiplied by the value of reference field (laboratory field) gives the intensity of ancient geomagnetic field $B_{\text {anc }}=\mathrm{NRM} / \mathrm{TRM} \cdot B_{\text {lab }}(\mu \mathrm{T})$, the value at the time of firing the samples.

The mean paleointensity value of the sample is found to be $48.71 \pm 0.16 \mu \mathrm{T}$. From the archaeologist point of view these samples belong to Iron Age (1000-500 BC), to obtain a more precise dating of the samples they can be subjected to ${ }^{14} \mathrm{C}$ dating.

\section{Conclusion}

Infrared spectroscopy has the potential to provide useful information on firing technique of pottery. The analysis of the samples shows that the shreds are fired above $600{ }^{\circ} \mathrm{C}$ under reducing/oxidising atmosphere and the type of clay used is disordered type. The main ferrimagnetic iron oxide minerals responsible for the magnetic susceptibility of burnt clay are magnetite with significant amount of superparamagnetic/single domain magnetite particles and hence suitable for paleointensity measurements. Remenance measurements, Q-ratio and S-ratio, point out the presence of ferrimagnetic mineral magnetite with SD/PSD state. The paleointensity value is found to be $48.71 \pm 0.16 \mu \mathrm{T}$.

\section{Acknowledgements}

The authors are grateful to Dr K. Rajan, Professor and Head, Department of History, Pondicherry University, Pondicherry, India for having provided the samples. The authors wish to thank Director Dr M. Baba, Centre for Earth Science Studies (CESS), Thiruvananthapuram for having permitted to carry out the magnetic measurements at Paleomagnetism Laboratory. One of the authors (R. I.) is thankful to Indian Academy of Sciences, Bangalore for awarding Summer Visiting Fellowship (2006).

\section{References}

[1] S. Gurumurthy, Ceramic Traditions in South India (Down to 300 A. D.), Madras University Archaeological Series No. 4 (University of Madras, 1981).

[2] M.C.B. Rodriguez and V.C. Alvarez, A preliminary archaeomagnetic study of prehistoric Amerindian pottery from Venezuela, Interciencia 24, 293-299 (1999).

[3] A.O. Shepard, Ceramics for the Archaeologist, Publication 609 (Carnegie Institution of Washington, Washington, DC, 1974).

[4] J.D. Russel, in: A Handbook of Determinative Methods in Clay Mineralogy, ed. M.J. Wilson (Chapman and Hall, Glasgow - Blackie \& Sons, New York, 1987). 
[5] R. Venkatachalapathy, T. Sridharan, S. Dhanapandian, and C. Manoharan, Determination of firing temperature of ancient potteries by means of infrared and Mössbauer studies, Spectrosc. Lett. 35, 769-779 (2002).

[6] R. Venkatachalapathy, D. Gournis, C. Manoharan, S. Dhanapandian, and K. Deenadayalan, Application of FTIR and Mössbauer spectroscopic analysis of some South Indian archaeological potteries, Indian J. Pure Appl. Phys. 41, 833-838 (2003).

[7] E. Murad and U. Wagner, Mössbauer study of pure illite and its firing products, Hyperfine Interact. 91, 685-688 (1994).

[8] E. Murad and U. Wagner, Clays and clay minerals: The firing process, Hyperfine Interact. 117, 337-356 (1998).

[9] N. Jordanova, E. Petrousky, M. Kovacheva, and D. Jordanova, Factors determining magnetic enhancement of burnt clay from archaeological sites, J. Archaeol. Sci. 28, 1137-1148 (2007).

[10] M. Kovacheva, N. Jordanova, and V. Karloukovski, Geomagnetic field variations as determined for Bulgarian archaeomagnetic data. Part II: The last 8000 years, Surv. Geophys. 19, 431-460 (1998).

[11] N. Abrahamsen, An archaeomagnetic mastercurve for Denmark 0-2000 AD and the possible dating accuracy, in: Proceedings of the Sixth Nordic Conference on the Application of Scientific Methods in Archaeology, Esberg Museum 1993, 261-271 (1996).

[12] J. Dearing, R. Dann, K. Hay, J. Less, P. Loveland, B. Maher, K. O'Grady, Frequency-dependent susceptibility measurement of environmental materials, Geophys. J. Int. 124, 228-240 (1996).

[13] T. Forster, M. Evans, and F. Heller, The frequency dependence of low susceptibility of ferrofluids, J. Phys. D 22, 449-450 (1994).

[14] U. Wagner, F.E. Wagner, W. Housler and I. Shimada, The use of Mössbauer spectroscopy in studies of archaeological ceramics, in: Radiation in Art and Archaeometry (Elsevier Science, 2000), pp. 417-443.

[15] S.N. Ghosh, Infra-red spectra of some selected minerals, rocks and products, J. Mat. Sci. 13, 1877-1866 (1978).

[16] M. Ishii and M. Nakahira. Infrared absorption spectra and cation distributions in $(\mathrm{Mn}, \mathrm{Fe})_{3} \mathrm{O}_{4}$, Solid State Commun. 11, 209-212 (1981).

[17] Jun Ojima, Determining of crystalline silica in respirable dust samples by infrared spectrophotometry in the presence of interpresences, J. Occup. Health 45, 94-103 (2003).

[18] R. Thompson and F. Oldfield, Environmental Magnetism (Allen \& Unwin, London, 1986).

[19] S.D. Mooney, C. Geiss, and M.A. Smith, The use of mineral magnetic parameters to characterize archaeological ochres, J. Archaeol. Sci. 29, 1-10 (2002).

[20] D.J. Dunlop and O. Özdemir, Rock magnetism. Funda- mentals and frontiers, in: Cambridge Studies in Magnetism, ed. D. Edwards (Cambridge University Press, 1997).

[21] H.U. Worm, On the superparamagnetic - stable single domain transition for magnetic, and frequency dependence of susceptibility, Geophys. J. Int. 133, 201-206 (1998).

[22] J. Dearing, P. Bird, R. Dann, and S. Benjamin, Secondary ferrimagnetic minerals in Welsh soils: A comparison of mineral magnetic detection methods and implications for mineral formation, Geophys. J. Int. 130, 727-736 (1997).

[23] Li-Li Tian, Ri-Xiang Zhu, and Yong-Xin Pan, Rock magnetic properties of Hannuoba Basalts, Zhangbei, China, Chinese J. Geophys. 45, 872-878 (2002).

[24] Ri-Xiang Zhu, Bin Guo, and Zhong-Li Ding, GaussMatuyama polarity transition obtained from a loess section at Weiman, North-Central China, Chinese J. Geophys. 43, 621-634 (2000).

[25] J. Blomendal, J.W. King, F.R. Hall, and S.H. Doh, Rock magnetism of Late Neogene and Pleistocene deep-sea sediments: Relationship with sediment source, diagenetic processes, and sedimentation lithology, J. Geophys. Res. 97, 4361-4375 (1992).

[26] M.W. McElhinny and W.E. Senanyake, Variations in the geomagnetic dipole, the past 50,000 years, J. Geomagn. Geoelectr. 34, 39-51 (1982).

[27] L.M. Alva-Valdivia, M.L. Rivas, A. Goguitchaichivili, J. Urrutia-Fucugauchi, J.A. Gonalez, J. Morales, and S. Gomez, Rock-magnetic and oxide microscopic studies of the E1 Laco iron ore deposits, Chilean Andes and implications for magnetic anomaly modeling, Int. Geol. Rev. 45, 533-547 (2003).

[28] Y. Cui, K.L. Verosub, A.P. Roberts, and M. Kovacheva, Rock magnetic studies of archaeological samples: Implications for sample selections for paleointensity determinations, J. Geomagn. Geoelectr. 49, 567-585 (1997).

[29] E. Thellier and O. Thellier, Sur l'intensité du champ magnétique terrestre dans le passé historique et géologique, Ann. Géophys. 15, 285-376 (1959).

[30] R.S. Coe, Paleo-intensities of the Earth's magnetic field determined from Tertiary and Quaternary rocks, J. Geophys. Res. 72, 3247-3262 (1967).

[31] M. Kono, Changes in TRM and ARM in basalts due to laboratory heating, Phys. Earth Planet. Inter. 46, 1-8 (1987).

[32] E. Thellier, Sur l'aimantation des terres cuites et ses applications géophysiques, Ann. Inst. Phys. Globe 16, 157-302 (1938).

[33] M. Prévot, E.A. Mankinen, R.S. Coe, and C.S. Grommé, The Steens Mountain (Oregon) geomagnetic polarity transition 2 . Field intensity variations and discussion of reversal models, J. Geophys. Res. 90, 10417-10448 (1985). 


\title{
ARCHEOLOGINIŲ INDIJOS PUODŲ ŠUKIŲ SPEKTROSKOPIJA IR SENOVĖS GEOMAGNETINIO LAUKO STIPRIO TYRIMAS
}

\author{
C. Manoharan ${ }^{a}$, K. Veeramuthu ${ }^{a}$, R. Venkatachalapathy ${ }^{b}$, T. Radhakrishna ${ }^{c}$, R. Ilango ${ }^{d}$ \\ a Anamalai universitetas, Annamalainagar, Indija \\ ${ }^{\mathrm{b}}$ Anamalai universiteto Jūru biologijos aukštesniuju studiju centras, Parangipettai, Indija \\ ${ }^{\mathrm{c}}$ Geomokslu studiju centras, Akkulam, Trivandrum, Indija \\ ${ }^{\mathrm{d}}$ Vivekananda koledžas, Mylapore, Chennai, Tamil Nadu, Indija
}

\section{Santrauka}

Atlikti archeologinių puodų šukių pavyzdžių (Mayiladumparai, Tamilnadu, Indija) spektroskopiniai ir senovès magnetinio lauko stiprio tyrimai. Apie molio mineralini tipą ir sandaros pokyčius dèl degimo spręsta iš Furje transformuotų infraraudonųu (FTIR) spektrų. Patikimai nustatyti maksimali degimo metu pasiekta temperatūra, degimo sąlygos (atmosferinès ar riboto sąlyčio su oru) ir geležies mineralinių fazių kitimai. Intensyviai tirtos šių pavyzdžių uolienų magnetinės savybės, siekiant atrinkti pavyzdžius senovės magnetinio lauko intensyvumo matavimams. Rezultatai parodè, kad visi pavyzdžiai buvo magnetiškai aktyvūs, su superparamagnetinèmis granulèmis, kurių Kiuri temperatūra $\left(580^{\circ} \mathrm{C}\right)$ tokia, kaip magnetito. Iš to seka vidutiné $48,71 \pm 0,16 \mu \mathrm{T}$ senovés magnetinio lauko stiprio vertè. 